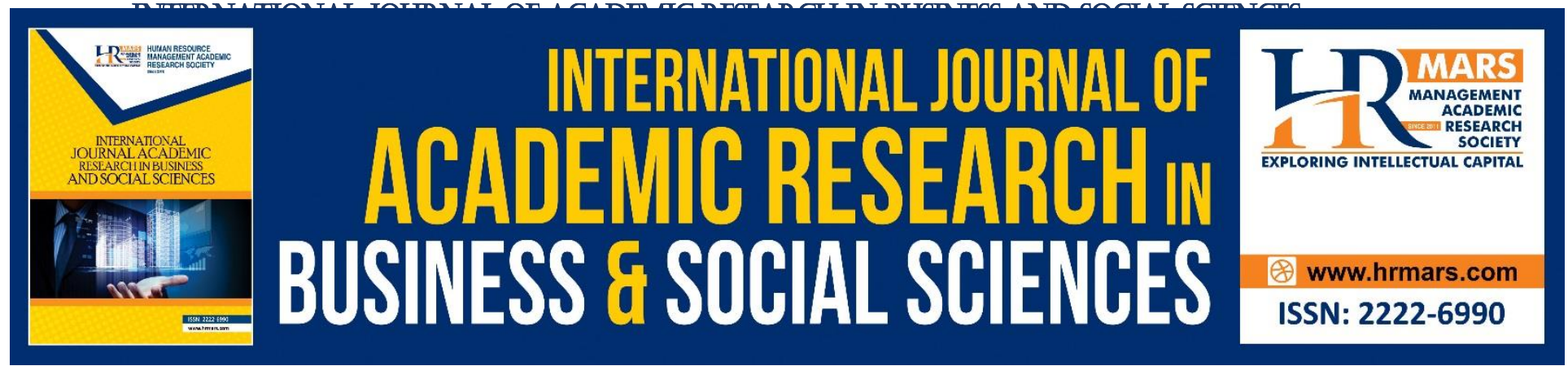

\title{
Program Planning Model: A Theoretical Guide for Designing Online Distance Education Courses
}

Nur Aira Abdrahim

To Link this Article: http://dx.doi.org/10.6007/IJARBSS/v8-i12/4990

DOI: $10.6007 /$ IJARBSS/v8-i12/4990

Received: 03 Nov 2018, Revised: 12 Dec 2018, Accepted: 15 Dec 2018

Published Online: 16 Dec 2018

In-Text Citation: (Abdrahim, 2018)

To Cite this Article: Abdrahim, N. A. (2018). Program Planning Model: A Theoretical Guide for Designing Online Distance Education Courses. International Journal of Academic Research in Business and Social Sciences, $8(12), 46-67$.

\section{Copyright: (c) 2018 The Author(s)}

Published by Human Resource Management Academic Research Society (www.hrmars.com)

This article is published under the Creative Commons Attribution (CC BY 4.0) license. Anyone may reproduce, distribute, translate and create derivative works of this article (for both commercial and non-commercial purposes), subject to full attribution to the original publication and authors. The full terms of this license may be seen

at: http://creativecommons.org/licences/by/4.0/legalcode

\section{Vol. 8, No. 12, 2018, Pg. 46 - 67}

http://hrmars.com/index.php/pages/detail/IJARBSS

JOURNAL HOMEPAGE

Full Terms \& Conditions of access and use can be found at http://hrmars.com/index.php/pages/detail/publication-ethics 


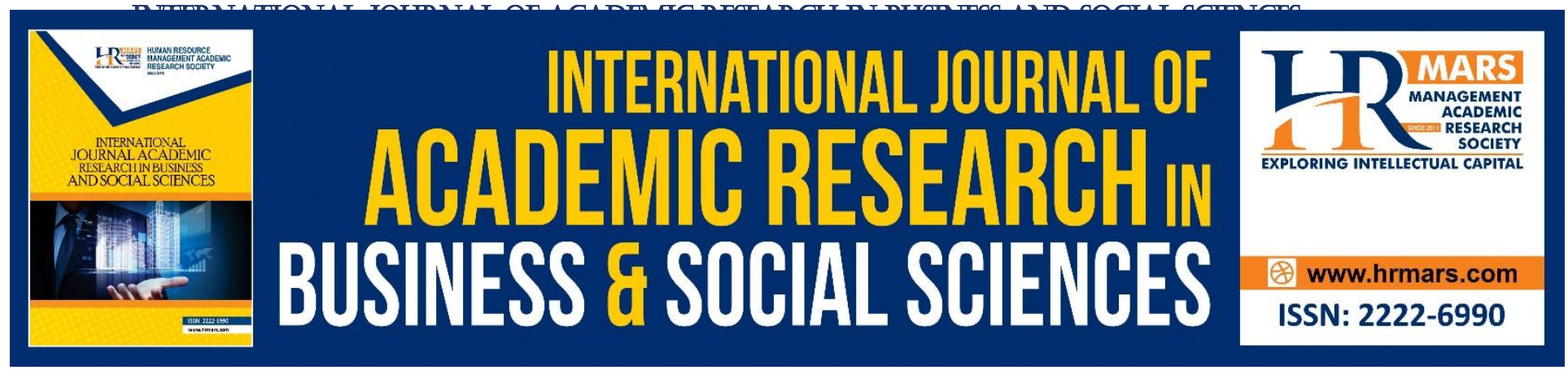

\title{
Program Planning Model: A Theoretical Guide for Designing Online Distance Education Courses
}

\author{
Nur Aira Abdrahim \\ Department of Continuing Education \& Professional Development, Faculty of Educational \\ Studies, Universiti Putra Malaysia
}

\begin{abstract}
Planning a university-based distance education was once considered a marginalized practice in higher education institutions (HEls). However, many changes have since taken place in HEls, not only from procedural and technological aspects, but also involving structural and cultural systemic changes in the existing organizational and educational practices. Universities are now expected to deliver courses not only in traditional face-to-face format, but to also inculcate various forms of distance and flexible learning as part of their course delivery to the students. Understanding context is an important aspect in program planning. By assessing the current context of distance education practice in higher education, this paper seeks to propose a program planning model as a theoretical guide for supporting the development of a successful learning design for distance learners, particularly for undergraduate courses. The first part of this paper discussed a selected program planning model from the adult education literature. The second part of this paper elaborates each of the planning component as supported the distance education literature. This paper concludes with a proposed skeletal model, specifically for designing online courses at the end.
\end{abstract}

Keywords: Distance Education, Program Planning, Online Course Design, Instructional Design, Online Instruction

\section{Introduction}

The literature in program planning has produced various models, theories and frameworks over the last 60 years (Sork, 2010). Program planning model is generally defined as "a set of steps, tasks, or decisions which, when carried out, produce the design and outcome specifications for a systematic instructional activity" (Sork \& Buskey, 1986, p. 87). Many program planning models, including those from adult education field, are dominated by a strong technical rationality tradition. Technical rationality view is rooted in the assumption that any well-defined problem can be instrumentally solved through a set of rational scientific inquiry (Forester, 1989; Schon, 1983; Wilson \& Cervero, 2006). 
On a more recent note, Sork (2010) also discusses three new contextual changes that need to be considered in contemporary program planning. The first consideration is on the idea of planning and delivery across borders and boundaries. As a result of globalization, higher education institutions are in great demand to internationalize their educational practices. As a result, planners and providers of education now have to take into consideration the impact of various contexts, cultural and language diversity, as well as different norms and traditions when designing their educational practices for the global population. In addition, there is a heightened awareness on the issues of diversity and inclusion among the society in general. Planners now assume a greater responsibility to consider issues such as accessibility, race, gender, language, sexual orientation, ableness, religion, economic circumstances, and facilities with language, among many others, when designing their program. The impact of digital technologies in educational practices has also emerged as a critical valuation in program planning. With many aspects of the learners' daily lives have been "digitalized", more learners are prone to expect the same "digital" changes to apply in their educational experiences. As observed by Sork (2010), "although those who work primarily in online learning are trying hard to stay on top of this wave, those working in more conventional formats must also adapt to this new reality" (p. 158).

With these changes in mind, Sork (2010) outlines few contemporary models of program planning that have recently been proposed or updated to address some new demands in program planning practices. One of the program planning models is based on Caffarella's (2002) interactive model of program planning. Caffarella's model is consists of twelve program planning components, where each component can be flexibility used and sequenced according to the planner needs. According to Warren (2000), Caffarella (2002) has thoroughly reviewed the program planning models from the past and taken the criticisms of practicing program planners into account to design her interactive model. When compared with other program planning models, there are two distinct features about Caffarella's program planning model that offer essential guidelines for supporting development of course designs in distance education context. First, the model incorporates both classical and contemporary elements of a program planning process, thus making it a useful generic programming model that can be applied to various contexts (Boone, Safrit, \& Jones, 2002). Secondly, the interactive model is flexible in a sense that it does not suggest a linear programming process that must include all steps or must be followed in steps or orders, but rather, planners may choose to begin or use only selected planning components that are applicable to their specific planning context. Several researchers, whose program design practices are nestled in the context of higher education, have found Caffarella's model to be useful in guiding their planning. For Sandman, Kiely, and Grenier (2009), they perceived Caffarella's (2002) model as suitable for understanding the role of context and practical decision making when planning service learning programs. Wiesenberg and Stacey (2005), in their reflections on teaching and learning online, have also speaks of Caffarella's interactive model as essential to help in course pre-delivery planning phase. Thus, this paper seeks to propose a theoretical guide for designing distance education courses based on the elements discussed in this particular program planning model.

\section{Program Planning: Overview of the Interactive Model}

Caffarella's (2002) interactive program planning is formulated using twelve components as follow: (1) discerning the context; (2) building a solid base of support; (3) identifying program 
ideas; (4) sorting and prioritizing program ideas; (5) developing program objectives; (6) designing instructional plans; (7) devising transfer-of-learning plans; (8) formulating evaluation plans; (9) making recommendations and communicating results; (10) selecting formats, schedules, and staff needs; (11) preparing budgets and marketing plan; and (12) coordinating facilities and onsite events.

Caffarella developed and built her model based on the previous program planning models, thus many of its key components reflect similarities from existing models in the literature. However, her model is distinctive in four ways: (1) it is interactive in design; (2) people and place are acknowledged as important in the planning process; (3) differences among culture are taken into account in the planning process; and (4) is considered as a practical tool by many practitioners. In this model, Caffarella provides her credo in program planning through seven set of assumptions. The first assumption speaks of program planning as focusing on what the participants actually learn and how the learning results in changes in participants, organizations, and/or societal issues and norms. The second assumption talks about the non-sequential nature of the planning process where it involves a complex interaction of institutional priorities, tasks, people, and events. The next assumption discerns on the importance of context and negotiation, where people plan programs within a social, economic, cultural, and political climate. The fourth assumption recognized program planning as attending to both preplanning and last minute changes. In the fifth assumption, diversity and cultural differences are highlighted as essential considerations in program planning. The sixth assumption is about accepting that program planners work in different ways and that designing educational programs is anything but an exacting practice. And the final assumption is about understanding that program planners are indeed learners themselves, who can learn to be more effective program planners through practice. Caffarella also pointed out that the first three assumptions listed are the most critical ones in her program planning model.

Out of the twelve components of her interactive model, Caffarella (2002) highlights six components as most central and critical to any planning process. These six components are: (1) discerning the context, (2) identifying program ideas, (3) developing clear program objectives, (4) designing instructional plans, (5) formulating evaluation plans, (6) and devising transfer-oflearning plans. In this paper, the theoretical guide is developed based on these six recommended critical components of Cafarella's model. While the interactivity and non-sequential nature of this model is recognized, for discussion purposes, this paper will elaborate each component in a linear way.

Step 1: Discerning the context. Caffarella describes three important facets of the planning context to include interacting with people, examining the organizational component, and looking at the wider environmental conditions. Contextual knowledge can be acquired from multiple sources, and few basic sources that Caffarella suggested include written documents, people, group meeting and gatherings, professional and trade associations, and technology-based sources. However, the most important consideration in applying contextual knowledge lies in three primary issues: the issues of power, willingness to negotiate, and ethical considerations. The following discussions will address all the key facets described in this step under the context of planning for online credit courses for undergraduate distance learners.

People. The people that are involved in a planning process differ depending on the planning situation. Large-scale programs usually have more complexity in terms of the 
interactions between stakeholders and culturally diverse settings. According to Roberts (1996), the planner of distance education course needs the gauge the information from two groups of people: 1) from those who develop and offer the courses; and 2) from those who participate. When considering the list of people from the first group, the planner needs to consider the people who are involved in the "planning table" within the social context (Cervero \& Wilson, 2006). In a typical academic department in higher education setting, this may include academics and faculty members, Dean and Department Head, administrative and technology support staff, librarians, and other related academic entities. If the online credit course is going to be offered to international students, planner may also want to include personnel from the Office of International Students for additional inputs. The second group of people to consider is the potential learners who will be taking the course. Many distance education instructional models highlight the needs to include and understand the learners when designing a course in distance learning setting (Dabbagh \& Bannan-Ritland, 2005; Rovai, Ponton, \& Baker, 2008; Simonson, Smaldino, Albright, \& Zvacek, 2009). Simonson et al (2009) discuss several reasons why. The nature of distance education has allowed learners from different backgrounds and location to participate in the one single course and resulted in growing plurality in the learners' characteristics. Knowledge of the learners' characteristics can guide many aspects of the program planning. For example, understanding the learners' origination and distance sites will help the instructor in planning the course logistics. Knowing the class size is also important as it can influence the level of interactivity in the course. Another essentiality is to understand the nature of the learners, in terms of their demographic characteristics, educational expectations, cultural, social and economic backgrounds as all these will affect the quality of the learning experience for all members of the class.

Organizational components. A credit course for undergraduate is often being offered through an academic department, may be part of a degree program requirements, and usually is subjected to the requirements as outlined by the higher education institution that provides the course. When considering the organizational components in planning a program, Caffarella (2002) suggests looking at three different aspects: structural, political, and cultural factors. Structural factors are usually factors related to the organizational blue prints, such as mission and objectives of the organization, and standard operating policies and procedures. Political factors may include things like coalition building, power relations, and politics of funding and distribution of resources. Cultural factors, involve factors such as history and traditions of the organization; organizational beliefs and values; and organizational rituals, stories, symbols, and heroes. Dabbagh and Bannan-Ritland (2005) discuss how these factors can affect the program planning in online distance learning context. Teachers and instructors may be bounded by strict guidelines in curricula and grading, limited policies and perspectives on learning, and may be required to conform their lessons to specific learning standards established by their course providers or accreditation governing bodies. In addition to these three factors, Dabbagh and Bannan-Ritland also add another factor that is especially vital in planning an online distance program, that is access to particular technological tools. Often time, instructors in higher education only have access to certain tools, such as the course management systems (CMS) that are provided by the university, thus their course design is confined within the availability of features that come with the provided tools. 
Wider environment. This facet involves studying the macro aspects of the environment, such as general economic, political, and social climate where the planners operate and function (Caffarella, 2012). Few examples include examining the economic conditions and the competitive marketplace, and looking at how it may influence the educational planners work and their program planning design. For instance, during bad economic time, instructors may want to consider changing their practice from requiring the learners to purchase an expensive textbook to supplying the instructional materials online. Globalization is another macro environment issue that is currently affecting the practice of online learning (Poley, 2010). A profound comment is made by Brown and Dugurd (2000) in noting that "online learning tempts centralization and overlooks the fact that much of what we learn is remarkably local" (as cited in Poley, 2010, p. 193). As the practice of education extends across the globe largely through the means of online learning, planners need to be more sensitive in the cultural and social differences between places when designing their distance learning course. Rovai, Ponton, and Baker (2008) illustrate several cultural differences than may affect learners' disposition and learning styles, such as high context versus low context cultures (Ibarra, 2001), and the culture of collectivism versus individualism (Hofstede, 2004). In addition, Prensky (2001) also points out that there is a new generation of students entering the universities known as the Digital Natives, who grew up and have been using digital technologies as part of their daily lives. These students have different sets of thinking and expectations, including on how they perceived and engaged in learning, thus requiring different sets of approaches in planning educational programs to account for this new set of thinking.

Issues of powers. There are dual aspects of power in program planning: the power that the planner has and the power possessed by whom they work with (Caffarella, 2002). Power has a central influence in directing what happens in the planning process, such as in shaping 'felt' needs, setting program agendas, making decisions, and allocating types and amounts of resources. When planning an online credit course for undergraduate distance learners, instructor may have less planning power than what is generally perceived. Rovai, Ponton, and Baker (2008) illustrate how institutional strategic planning can influence the planning directions of distance education programs. Strategic planning in higher education is described by Rowley, Lujan, and Dolence (1997) as a "formal process design to help a university identify and maintain an optimal alignment with the most important elements [of] the environment ... within which the university resides. [This environment consists of] the political, social, economic, technological, and educational ecosystem, both internal and external to the university" (as cited in Rovai, Ponton, and Baker, 2009, p. 47)

When outlining strategic planning, university has already established the institution's own needs and agendas, and thus will have the power to direct their sub-entities, such as Colleges and Department Programs, to align their academic practices in support of the strategic planning. The issue of power can also come from the external environments, such as policy makers and government agencies. One example from online learning situation is through the new stricter ruling from the U.S. Education Department on the accreditations of online learning programs (Kelderman, 2011). In order to achieve the accreditation, program planners will have to conform to the guidelines and ruling from this agency, thus impacting how the online program is being shaped.

Negotiations. Caffarella (2002), drawing from the work by Cervero and Wilson (1998), distinguished two levels of negotiations during the planning process. Substantive negotiations 
refer to related negotiations about the features of educational programs, while metacognition negotiations is a complex process of negotiating between the social and political relationships of those who are included and excluded. For planners of online learning course, the negotiation tasks may include gaining support and agreements from their colleagues and superiors in the course planning, and seeking buy-ins from important stakeholders such as the university administrations (Dabbagh \& Bannan-Ritland, 2005).

Ethical considerations. Ethical considerations added another layer in the complexity of program planning. Challenges in this facet may include clashes of beliefs and values between the planners and their home institutions. Chau (2010) has voiced a concern over the commercialization of online programs by some educational institutions that resulted in the manipulation of faculty's knowledge into sellable products and compromised quality of education. In this regard, program planners with strong educational beliefs may face ethical dilemmas in deciding whether to conform to the business-oriented practice or leave the respective institution.

Another important ethical consideration in online program planning is the issues of copyright, intellectual property, and the standards fair use for distributions (Dabbagh, \& BannanRitland, 2005; Rovai, Ponton, and Baker, 2008; Simonson et al, 2009). With the recent digital technologies and Internet access, one of the main issues that online program planners need to understand is the distinctions between violation of copyright or use that are protected under the law of fair use. Dabbagh and Bannan-Ritland (2005) discuss the legal definitions between copyright and intellectual law. According to Poltorak and Lerner (2002), from a legal perspective, any class item that falls under the following criteria is considered as an intellectual property:

- An author's original creation expressed in any medium, including pictorially, lexically (textually), or recorded by digital or analog means

- A new invention that has utility

- A text and/or graphic that identifies a provider of services or goods

(as cited by Dabbagh \& Bannan-Ritland, 2005, p. 57).

Depending on the criteria above, different legal protection is provided to protect a different type of intellectual property. Copyright law is in use to protect intellectual property that falls under the first criteria, and is considered the most common intellectual property used and developed in educational contexts (Dabbagh \& Bannan-Ritland, 2005). To account for the emerging online classroom instructions, a new law of fair use was enacted in 2001, allowing students and instructors to use copyrighted-protected material, including transmission of copyrighted digital media over the Internet, as part of an instructional course offered by nonprofit educational organization (TEACH Act, 2002). While most work in educational context is usually covered under the fair use terms, online program planners are often presented with several ethical challenges in deciding and selecting the resources that they can use and distribute in fairly and legally acceptable manners.

Step 2: Identifying program ideas. This component is concern with the content of the planned program (Caffarella, 2012). In general program planning, ideas for programs may come from diverse sources based on personal observations to highly structured needs assessments.

Comparably, Morrison, Ross, Kalman, and Kemp (2001) refer to this step as task analysis in their instruction design model. There are two roles involved in the process of task analysis, a subject-matter expect and instructional designer. In educational settings, the instructor often 
serves as both the subject-matter aspect and the instructional designer. They distinguished three types of procedures: topic analysis, procedural or information-processing analysis, and critical incident methods. Task analysis helps identify content and the nature of the structure of the intended instruction (such as facts, concepts, procedures, etc). Procedural or information analysis is used to analyze tasks by identifying the steps required to complete them. Both procedures are suitable for determining program with concrete content and highly structured tasks. For a more varied and fluid situations, a critical incident analysis, a method based on asking sets of questions via interviews, is recommended as a tool to help identified the needs and suitable program content.

In Dabbagh and Bannan-Ritland's (2005) integrated learning design framework for online learning, they described a similar step during the exploration phase. The purpose of the exploration phase is to collect all necessary information needed to inform the online program design. Specific activities involved in the exploration phase include:

- Documenting insights and findings from the gathered information

- Collect information about the instructional context

- Examine individual perspectives on the learning process

- Incorporate published perspectives on the learning process

- Solicit perspectives and existing information on the learning process, content, and online delivery method.

(Dabbagh and Bannan-Ritland, 2005, p. 121)

They also proposed a list of formal and informal methods to guide online instructors during their exploratory phase. Examples of informal methods include individual reflection, group discussion, reviewing past online course and lesson examples, examining relevant documentation, discussions with colleagues and getting additional expert opinions. In addition, program planners can also gather program ideas through formal methods such as gathering information from formal report and action research plan, conducting needs assessment, examining the literature, participate in learning circles, conducting contextual and qualitative analyses, developing survey and focus groups, and having expert panel.

Step 3: Developing clear program objectives. Under this component, Caffarella (2002) differentiates between two types of objectives, program goals and program objectives. Program goals refer to the program's broad statements of purpose, and may be related to institutional missions. For example, Rovai, Ponton, and Baker (2008) discuss how university's strategic planning can influence the objectives of distance education programs, where the objectives may include improving students' access and satisfaction in their learning experiences.

Meanwhile, program objectives specifically outline the anticipated educational outcomes of a program. It is primarily centered on what the learners will generally learn by participating in the program or in a course, and may also address the operational aspects of the program. Program objectives are foundational to developing the instructional and transfer-of-learning plans, and also serve as benchmarks for programs evaluations. In addition, program objectives may also reflect the specific principles of the pedagogical approach used to design the program. At current, many authors have reported on a favorable shift to constructivist approach in designing online college learning programs (Barr \& Tagg, 1995; Dabbagh \& Bannan-Ritland, 2005; Harasim, 2000; \& Rovai, 2004). Under this shift, many online programs and courses are designed 
to include various learner-centered components directed to promote constructivist learning outcomes such as providing authentic learning experiences and encouraged active learning participation.

Step 4: Designing instructional designs. Preparing instructional plans involves designing the medium of interaction between learners and instructors, and/or learners' engagement with the resource materials (Caffarella, 2002). This step involves several sub-processes, which include formulating learning objectives, selecting and organizing content, selecting instructional techniques, and preparing the instructional assessment.

Learning objectives. The first step in designing instructional plan involves developing learning objectives that echo the program objectives formulated in the earlier stage. This is an important aspect in order to maintain the continuity between the two sets of objectives. These two sets of objectives are distinguished by its key focus. Program objectives are focused on the educational outcomes of the program as a whole, while learning objectives identify in specificity what the learners will learn as a result of attending the educational program or course. Learning objectives are essential and useful for planners as it guide the course design and evaluation, and influence the selection of the course content and the instructional methods. It is also a valuable tool to help learners guide and monitor their own learning. Learning objectives is also known as the instructional objectives (Morrison et al, 2011). Traditional instructional objectives are usually developed around three domains: cognitive, psychomotor, and affective. Cognitive domain refers to instructional objectives related to the acquisition, naming, solving, and predicting information and knowledge, plus other cognitive intellectual aspects of learning. Psychomotor domain addresses the related skills of performing and engaging with the content of learning, while affective domain involves objectives related to attitudes, appreciation, values, and emotions. Caffarella also discusses similar categories of learning domains, looking at acquisition of knowledge, cognitive skills, psychomotor skills, problem solving, and changes in attitudes, values, beliefs, and feelings. Simonson et al (2009) pointed out that the traditional approach for writing objectives is just as effective for distance education courses because the intended learning outcomes may not necessarily be changed simply because the course is being teach online and at distance.

Selecting and organizing content. Caffarella (2002) suggests using learning objectives as the starting point for selecting content. Content selection can be based around three key questions: (1) What participants must know; (2) What participants should know; and (3) What participants could know. Simonson et al (2002) also discuss several aspects to consider when deciding content for a course. First of all, the content needs to reflect where it relates to the rest of the curriculum. A credit course program is usually structured in a length of one academic semester, thus the amount of content must be decided optimally based on the given time frame. In addition, the scope of the content also needs to be sufficient to ensure that course will lead to the desired learning outcomes.

This component also involves organizing or sequencing the content. Caffarella (2002) suggested several guidelines, few selected as follow:

- Introduce key concepts, ideas, and terms early and revisit them throughout the instructional unit

- Explore materials familiar and less difficult to the participants first, and then process to the less familiar and more difficult 
- Ensure prerequisite knowledge and skills are taught prior to moving to content that builds on these materials

- Provide for instructional activities that allow for learning transfer throughout the instructional segment

$$
\text { (Caffarella, 2002, p. 173) }
$$

When organizing content, Caffarella asks that planners to be mindful of three things: time allowed, learners' motivation to absorb the amount of content, and context in which the learning is to be applied. In addition, sequencing content also has to be considered based on the characteristics of the learners, their prior knowledge, the nature of the content, and time factor (Simonson et al, 2009).

Selecting instructional techniques. In selecting the appropriate instructional technique for the program design, Caffarella (2012) outlines ten major factors to be considered. The ten factors are learning objectives, instructors, learners, context, transfer-of-learning, content, technique characteristics, variety, logistical constraints, and time. She also highlights the first four as the key factors, while the six following factors are weighted relatively based on the contextual nature of the learning situation. Many of these factors are considered based on the contextual knowledge of the program that was discerned earlier during Step 1. In the first factor, instructional techniques are selected based on its perceived learning outcomes that support the learning objectives. For example, simulations and demonstrations techniques are considered instructional techniques that support the learning outcomes of developing the learners' psychomotor skills. Bonk and Dennen (2007) proposed several online pedagogical activities based on the thinking and learning model, suggesting activities such as Delphi techniques, field reflections, online case analyses, and virtual debates to foster critical thinking; brainstorming, role playing, and topical discussions to encourage creative thinking; and symposia, web buddies, structured controversy in order to foster collaborative learning outcomes.

The second factor lies on the capability of the instructor, based on the instructor's knowledge, skills, and confidence to employ and facilitate a particular technique in an instruction. Competencies of good online instructors include those who posses good interpersonal skills, promotes interaction and collaborations among the learners in the learning process, and have good comprehension of learning technologies and how to use the tools effectively with the learners (Dabbagh \& Bannan-Ritland, 2005). Bonk and Dennen (2007) outlines four roles that online instructors can assume in thinking about ways that they can teach online. The first role, pedagogical role, is associated with roles in facilitating the learning, such as moderating questions, encourage student knowledge building, elicit reflection, weave or summarize discussions, offer constructive criticism, and provide explanations and elaboration when necessary. To support this role, online instructors can utilize instructional strategies such as problem-based learning tasks, peer feedback tools, discussion forums, role-play, online debates, constructive controversy and field reflections. The second role is the social role, where instructors can seek to create a friendly and nurturing environment, foster some humor, offer personalization in messages, display empathy and interpersonal outreach, and create community feel. Several examples of features and strategies that can be used include digitized class pictures, online guests and visitors, jokes, online stories or anecdotes. In managerial role, instructors assume the role in coordinating assignments, assign groups, grading, providing learning feedback, and the overall course structuring. Instructors can make use of online tools such as 
online chats, course FAQs, calendar of events, online grade book and portfolios for managing this role. In addition, instructors also assume technological role in assisting participants with technology issues, clarify problems encountered, and ensuring sufficient access by means of providing orientation tasks, help systems, and tutorials to the students.

The third factor that influences the selection of instructional techniques is based on the learners' characteristics. Several considerations include the multiple ways learners' learn, the social and cultural influences, prior knowledge and experiences, educational expectations and motivations, and other related demographic characteristics. For example, learners coming from a collectivist culture will value more collaborative instructions, while learners from high context culture will value more visual cues in their instructions (Rovai, Ponton, \& Baker, 2008). Employing multiple instructional strategies will help to account for the plurality characteristics of online learners. In addition, learners' access to technological tools must also be taken into consideration when selecting instructional strategies and tools to use in online learning program.

Learning context is the final key factor that considers the setting where the learning takes place. Some techniques can be more effective in certain learning settings than others, for example in the case of online learning. Selecting instructional techniques is the heart of many design frameworks in distance and online learning literature. In their integrated learning design framework, Dabbagh and Bannan-Ritland (2005) describes the enactment phase as the process of generating instructional strategies that are congruent with theories or learning and the instructional context. They define instructional strategies as "the plans and techniques that the instructional designer uses to engage the learner and facilitate learning" (p. 203). In their view, the selected pedagogical model of the learning design should inform both the selection of instructional strategies used and the associated Web technologies that support the instructional strategies. Dabbagh and Bannan-Ritland's framework favors the constructivist-based pedagogical approach. In constructivist approach, the instruction is designed to enhance active learner's participation and promote the process of constructing knowledge rather than simply communicating it. Several other instructional attributes of constructivist-based pedagogical approach include promoting authentic learning, encouraging collaboration and social negotiation, and exploration of knowledge. Instructional strategies that can be used to support these learning outcomes include simulations, problem-based learning, cognitive apprenticeships, and anchored instructions. Online courses should also utilize more use of media to support the instructional strategies (Simonson et al, 2009).

There are many reports on the current shift in educational practices towards the constructivist approach to learning (Barr \& Tagg, 1995; Brown, 1990; Harasim, 2000; Alonso, Lopex, Manrique, \&Vines, 2005). Kim (2005) has found that constructivist approach in teaching influence positive academic achievement and is more favorable by the students than the traditional teaching methods. In distance learning environment, constructivist pedagogical design can provide more optimal learning experiences to distance learners because it encourages the students' engagement, participation, and collaboration and help to overcome the social barriers of learning in distance (Naidu, 2007).

Preparing for instructional assessment. Caffarella described three types of instructional assessments: assessment at entry, assessment for resources and process, and assessment of results or outcomes. The purpose of assessment at entry is to inform the instructional development process by gauging the learner's prior knowledge and readiness to learn. Assessing 
the process and resources will help planners improve their instructional process and materials, while assessment for results or outcomes is use to determine if the instructions meet the expected learning outcomes. Data from the instructional assessments then can be use to inform the overall program evaluation.

In instructional course design, Simonson et al (2009) discuss two types of instructional assessments: formative and summative assessments. Formative assessment is usually implemented during the course in order to assess the ongoing learning process. This may include mid term quiz to assess if learners are learning the materials accordingly, or mid semester survey to gauge their opinion about the materials and course instructions thus far. The purpose of this is to provide feedback in time to make adjustments and revisions needed to provide better learning outcomes by end of the course. In addition, this could also include informal assessments, where instructor initiate dialogue with students, stimulate their construction of knowledge, and query for evidence of understanding and thinking (Rovai, Ponton, \& Baker, 2008). These formative activities support more regular interaction, more reflective interactions, and widespread dissemination of feedbacks. These are elements of importance in online learning environments that can help students improve their learning and inform instructors on any weaknesses related to their teaching or during the student's learning process.

On the other hand, summative assessment is related to measuring learning outcomes. Simonson et al define learning outcome as "a consequence of teaching and learning - of instruction and study" (p. 156) Summative assessment is directed towards appraising the final learning outcomes of a course and is ultimately use for grading. Simonson et al suggest several instructional assessment strategies that can be applied in distance learning environments, such as online quizzes, discussion forum and students-moderated discussions through asynchronous communication, presentations through synchronous communication, portfolios, paper and essay writing through online document sharing resources, and online journaling. Selection of instructional assessments to use is closely related to the learning objectives (Morrison et al, 2011). Several traditional instructional assessments, like objective and constructed-response tests are known to be more suitable to assess learning objectives related to acquisition of relevant knowledge. However, in the spirit of constructivist approach in online learning, Rovai, Ponton, and Baker (2008) suggest moving away from these traditional assessments. Instead, they recommend incorporating assessments that are grounded in providing more authentic learning experiences, collaboration and active participation opportunities for the students. Suggestions include implementing students' self-assessment, and assigning projects grounded in the context of learning and collaborative group work.

Step 5: Formulating evaluation plan. In her model, Caffarella (2002) distinguished between two levels of evaluations. Caffarella describes the first level of evaluation as instructional assessments, referring to assessments developed as part of an instructional design. This assessment is conducted while developing and during the implementation to improve the instructional design, and also as measure of learning outcomes. Meanwhile, program evaluation is another evaluation step in program planning, referring to a process used to evaluate the overall design and delivery of a planned program. The following table illustrated how both level evaluations can be used in academic program planning: 


\begin{tabular}{|c|c|c|c|}
\hline $\begin{array}{r}\text { Levels } \\
\text { of evaluation }\end{array}$ & Component & Purposes & $\begin{array}{l}\text { Utilization in academic } \\
\text { course planning }\end{array}$ \\
\hline \multirow[t]{2}{*}{$\begin{array}{l}\text { Instructional } \\
\text { assessments }\end{array}$} & $\begin{array}{l}\text { Component of } \\
\text { instructional } \\
\text { design }\end{array}$ & $\begin{array}{l}\text { 1. To inform the development } \\
\text { and revision of instructional } \\
\text { design }\end{array}$ & $\begin{array}{l}\text { 1. Use to improve course } \\
\text { design and revision } \\
\text { 2. Use to measure course }\end{array}$ \\
\hline & & $\begin{array}{l}\text { 2. To measure instructional } \\
\text { learning outcomes } \\
\text { 3. To provide data for program } \\
\text { evaluation }\end{array}$ & $\begin{array}{l}\text { learning } \\
\text { (examination results, } \\
\text { grades) } \\
\text { 3. Use to inform course } \\
\text { evaluation }\end{array}$ \\
\hline $\begin{array}{l}\text { Program } \\
\text { evaluation }\end{array}$ & $\begin{array}{l}\text { Component of } \\
\text { program } \\
\text { planning }\end{array}$ & $\begin{array}{l}\text { To measure overall program } \\
\text { outcome }\end{array}$ & $\begin{array}{l}\text { Use as overall course } \\
\text { evaluation }\end{array}$ \\
\hline
\end{tabular}

Caffarella (2002) outlines several important characteristics of program evaluation. Its core purpose is to determine whether the design and delivery of a program were effective and whether the proposed outcomes were met. Program evaluations can take into account both systematic planned evaluations as well as informal and unplanned evaluation activities. As a component that evaluates the overall program planning design, program evaluation design should connects all the information from other planning components to inform the evaluation outcomes.

Two types of evaluations are distinguished. Formative evaluation is the type of evaluation that is designed to collect information in order to improve or change a program while it is in process. Summative evaluation refers to evaluation that focuses on the results or outcomes of a program. In the context of planning a distance education program in higher education, the focus of formative evaluation is on academic quality management, mainly looking at the needs of program clients (i.e. distance education students), the delivery of the program or technology, and the quality of its implementation (Rovai, Ponton, and Baker, 2008). Meanwhile, summative evaluation is used to investigate the overall quality and impact of a distance education program, and is often associated with accountability purposes such as program accreditation.

Dabbagh and Bannan-Ritland's (2005) discuss two distinctive issues related to evaluating an online distance-learning program. The first one is on the issue whether evaluation efforts should separately examine the technology delivery media and the instructional strategies used in online program or if it should be evaluated on the combination basis of those two components. Clark (2000) believes that online learning planners should evaluate the delivery technologies and the instructional strategies separately. He suggests that technology features of a delivery technology can be evaluated separately based on its access, usefulness, and reliability. His suggestion is based on his beliefs that all instructional strategies can be delivered by any delivery technology. Thus, Clark believes that online learning developers should focus their evaluation efforts on the impact of the instructional strategy rather than on the technology features of the delivery system. For example, in this sense, instructor who delivered their instruction via Moodle should focus their evaluation on their instructional strategies instead of examining how their strategies is being delivered through features in Moodle. Kozma (2000) however, believes that 
the integration between instructional strategies and delivery technology are essential in online learning evaluation. He believes that evaluations effort in online learning design should examine the combination between instructional strategies and delivery technologies in looking at how these two elements intersect in a specific learning context. The second issue related to online program evaluation is on determining the best approach to evaluate a constructivist online learning environments since traditional evaluation methods do not support what Gunawardena, Lowe, and Carabajal (2000) described as the "open-ended nature of online learning, the multiple threads of conversation and fluid participations patterns" (as cited in Dabbagh \& Bannan-Ritland, 2000 , p. 238). Among the suggestions to address this include developing evaluations that focuses on higher order thinking skills rather than focusing on a single indicator (e.g. looking at how problem based learning are being solved rather than focusing on what is the solution provided), design evaluations in contexts that are as rich and complex as the instructional environments, and employ a variety of evaluation methods when possible to account for multiple perspectives in the learning outcomes.

Taking the dynamic nature of online learning into account, Dabbagh and Bannan-Ritland (2005), in the evaluation phase of their integrated learning design framework, suggest an approach to incorporate multiple methods (formal and/or informal), multiple perspectives (learner, colleague, stakeholder, management, administration), and multiple levels (learners' reaction, learning, behavior changes, and organizational results) as components of effective online programs evaluations. On a similar note, Cohen (2003) also proposed a model for assessing online distance learning instructions by examining the multiple constructs on the process of teaching and learning, community of learners, the instructor, the students, implementation of the course, and technology use.

Step 6: Devising transfer-of-learning plans. Transfer-of-learning plan emphasizes on the applicability of the knowledge and aims to ensure that program participants are transferring what they learned to their working context. The plan is grounded upon and linked primarily to five components of the Interactive Model of Program Planning: the context (people, organization, and wider community), program ideas and needs, program objectives, instructional plans, and program evaluation. Among the factors influencing the transfer of learning are program participants, program design and execution, program content, changes required to apply learning, organizational context, and community and societal forces as a whole.

In online learning program, transfer-of-learning among students are commonly associated with the increased in students skills and knowledge for future applicability in their working context. In order to provide the optimal learning experiences to online students, the constructivist approach in learning is recommended (Naidu, 2007). As cited by Dabbagh and Bannan-Ritland (2005), the principles of constructivist aim to provide the following instructional conditions to learners:

1. Embed learning in complex, realistic, and relevant contexts

2. Provide for social negotiation as an integral part of learning

3. Support multiple perspectives and the use of multiple modes of representation

4. Encourage ownership in learning

5. Nurture self-awareness of the knowledge construction process

(Driscoll, 2000, p. 382). 
This approach aims to promote authentic learning experiences and encourage knowledge construction and exploration, with hope to equip students with skills to transfer to their own working context whenever and wherever they are applicable.

\section{Summary and Conclusion}

Sork and Buskey (1986) define program planning model as "a set of steps, tasks, or decisions which, when carried out, produce the design and outcome specifications for a systematic instructional activity" (p. 87). As with many other program designs, the aim of program planning is to design an optimum learning environment to the learners. For distance learners, the aims include to provide them with content that they feel is relevant to their needs, clear directions for what they should do at every stage of the course, as much control on the pace of learning as possible, a way of testing their progress and getting feedback from instructors, and access to materials that are useful, active, and interesting (Moore, 1998). Based on Caffarella's (2002) interactive model of program planning, and integrated discussions from distance and online learning supports literature, the following skeletal model (Table 1.0) for designing an online credit course for undergraduate distance learners is proposed as a conclusion. 
Table 1.0

Skeletal program design for online undergraduate semester credit course

\begin{tabular}{|c|c|c|c|c|c|}
\hline \multicolumn{6}{|l|}{ ffarella's (2002) Ir } \\
\hline & & & & & \\
\hline $\begin{array}{l}\text { 1. Discerning the } \\
\text { context }\end{array}$ & $\begin{array}{lr}2 . & \text { Identifying } \\
\text { program objectives }\end{array}$ & S & $\begin{array}{l}\text { 4. Designing instructional } \\
\text { plans }\end{array}$ & $\begin{array}{l}5 . \quad \text { Fol } \\
\text { evaluation }\end{array}$ & $\begin{array}{l}\text { Devising } \\
\text { ransfer } \\
\text { earning plans }\end{array}$ \\
\hline $\begin{array}{l}\text { Acquiring contextual } \\
\text { knowledge related to } \\
\text { the program planning } \\
\text { a. People } \\
\text { - Academic entities on } \\
\text { the planning table: } \\
\text { Dean, Department } \\
\text { Head, fellow faculty, } \\
\text { admin and technology } \\
\text { support staff, librarian, } \\
\text { teaching assistant } \\
\text { - Assessing Learners: } \\
\text { Location, class size, } \\
\text { prior knowledge, } \\
\text { educational bultural, } \\
\text { expectations, cula } \\
\text { social, economic } \\
\text { backgrounds } \\
\text { b. Organization } \\
\text { - Structural: } \\
\text { organizational blue }\end{array}$ & 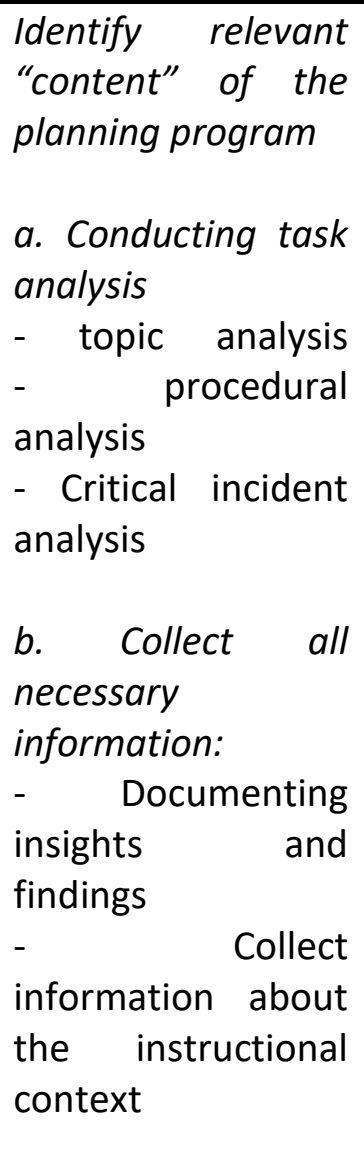 & $\begin{array}{l}\text { Provide clear } \\
\text { statements of the } \\
\text { anticipated } \\
\text { educational results } \\
\text { a. Program goals } \\
\text { - Program's broad } \\
\text { statements of } \\
\text { purpose } \\
\text { - May be related to } \\
\text { institutional } \\
\text { missions } \\
\text { university's } \\
\text { strategic planning } \\
\text { for distance and } \\
\text { online program } \\
\text { b. Program } \\
\text { objectives } \\
\text { - What are the } \\
\text { anticipated } \\
\text { educational } \\
\text { outcomes of a }\end{array}$ & 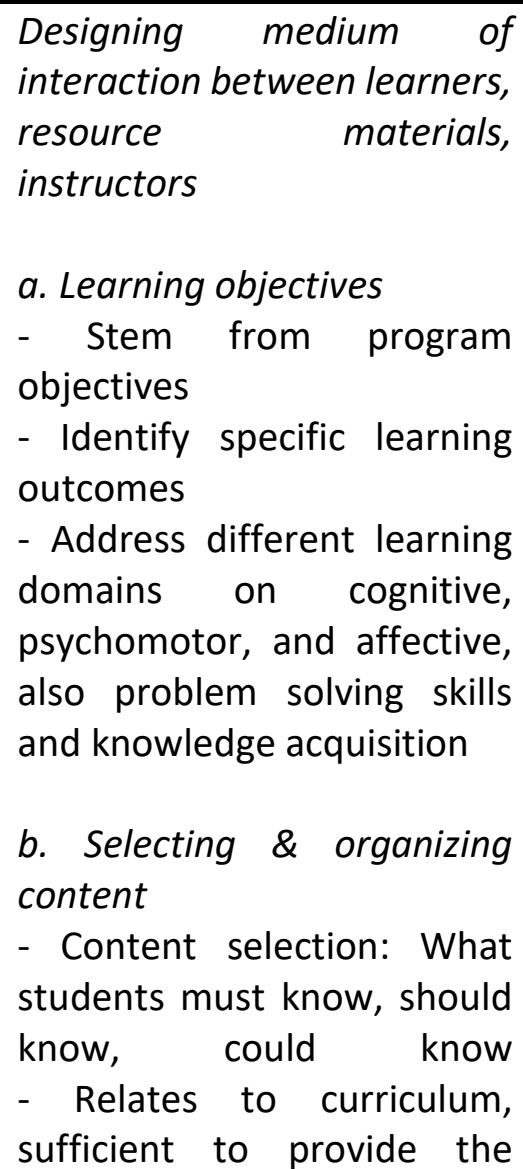 & $\begin{array}{l}\text { Evaluating the } \\
\text { overall design and } \\
\text { delivery of a } \\
\text { planned program } \\
\text { a. Formative } \\
\text { evaluation } \\
\text { - To collect } \\
\text { information in } \\
\text { order to improve or } \\
\text { change a program } \\
\text { while it is in } \\
\text { process on } \\
\text { - Focus on } \\
\text { academic quality } \\
\text { management } \\
\text { (clients of distance } \\
\text { education, delivery } \\
\text { of the program or } \\
\text { technology, quality } \\
\text { of implementation) } \\
b . \quad \text { Summative } \\
\text { evaluation }\end{array}$ & $\begin{array}{l}\text { Devising plans } \\
\text { for knowledge } \\
\text { transfer to the } \\
\text { working context } \\
\text { - Linked to } \\
\text { context (people, } \\
\text { organization, } \\
\text { and wider } \\
\text { community), } \\
\text { program ideas } \\
\text { and needs, } \\
\text { program and } \\
\text { objectives, } \\
\text { instructional } \\
\text { plans, } \\
\text { program analion. } \\
\text { evaluation }\end{array}$ \\
\hline
\end{tabular}




\begin{tabular}{|c|c|c|c|c|c|}
\hline $\begin{array}{l}\text { objectives, standard } \\
\text { operating policies and } \\
\text { procedures } \\
\text { - Political: coalition } \\
\text { building, power } \\
\text { relations, and politics } \\
\text { of funding, } \\
\text { distribution } \\
\text { resources } \\
\text { - Cultural: history \& } \\
\text { traditions, } \\
\text { organizational beliefs } \\
\text { and values } \\
\text { - Access to } \\
\text { technological tools }\end{array}$ & $\begin{array}{l}\text { - } \\
\text { individual } \\
\text { perspectives on the } \\
\text { learning process } \\
\text { - Incorporate } \\
\text { published Solicit } \\
\text { perspectives on the } \\
\text { learning process } \\
\text { - } \quad \text { perspectives and } \\
\text { existing process, } \\
\text { information on the } \\
\text { learning procing } \\
\text { content, and online } \\
\text { delivery method. } \\
\text { Formal methods: } \\
\text { - formal report } \\
\text { - action research } \\
\text { - needs assessment } \\
\text { - - literature } \\
\text { - learning circles } \\
\text { - contextual and } \\
\text { qualitative analyses } \\
\text { - survey individual } \\
\text { - focus groups } \\
\text { - expert panel. } \\
\text { Informal methods } \\
\text { - }\end{array}$ & $\begin{array}{l}\text { program? } \\
\text { - Address the } \\
\text { operational aspects } \\
\text { of the program } \\
\text { - Reflect the specific } \\
\text { principles of the } \\
\text { pedagogical } \\
\text { approach use to } \\
\text { design the program } \\
\text { i.e. constructivist } \\
\text { approach in } \\
\text { providing authentic } \\
\text { learning } \\
\text { experiences to } \\
\text { learners }\end{array}$ & 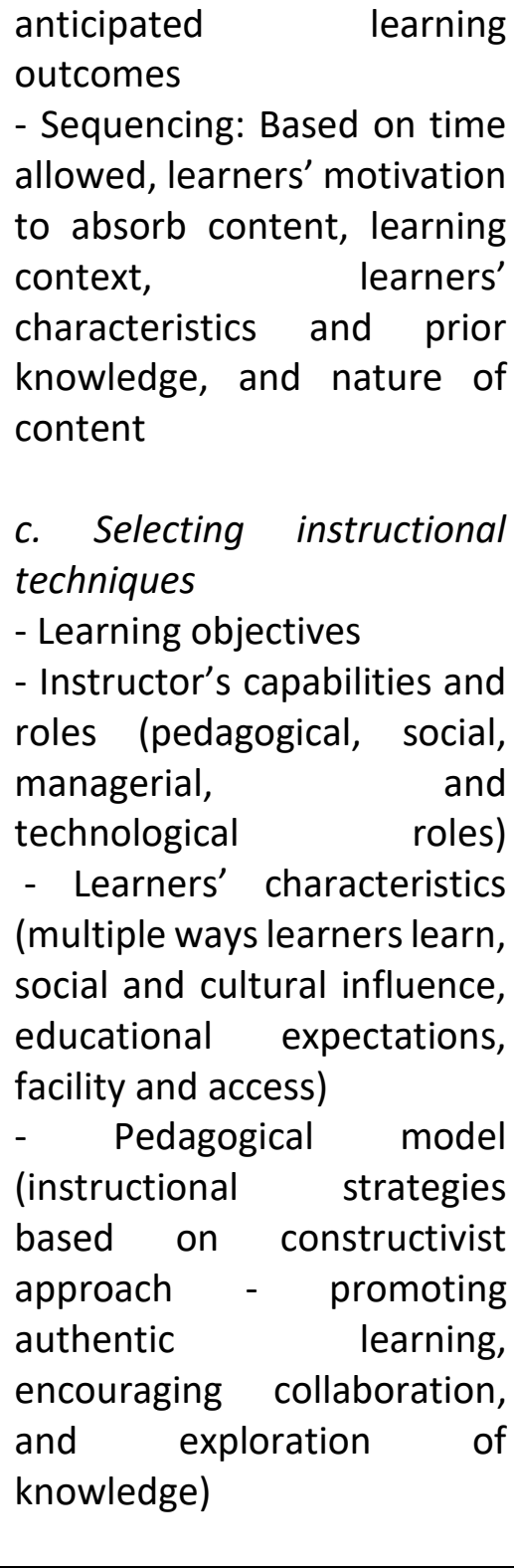 & 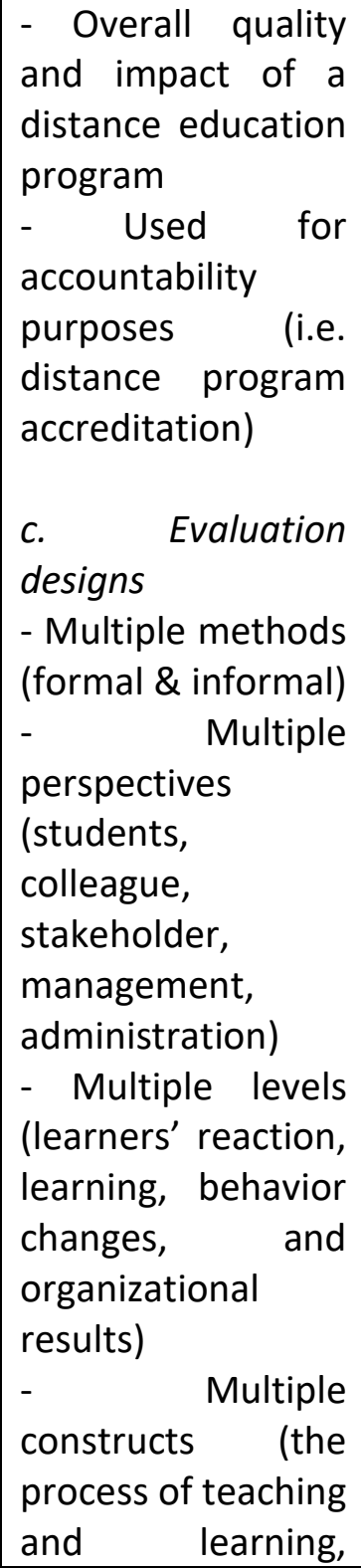 & $\begin{array}{l}\text { - Providing } \\
\text { optimal } \\
\text { experiences } \\
\text { through the } \\
\text { following } \\
\text { instructional } \\
\text { conditions: } \\
\text { i. } \\
\text { learning } \\
\text { complex, } \\
\text { realistic, } \\
\text { relevant and } \\
\text { contexts } \\
\text { ii. Provide for } \\
\text { social } \\
\text { negotiation as an } \\
\text { integral part of } \\
\text { learning } \\
\text { iii. } \\
\text { multiple Support } \\
\text { perspectives and } \\
\text { the use of } \\
\text { multiple modes } \\
\text { of }\end{array}$ \\
\hline
\end{tabular}




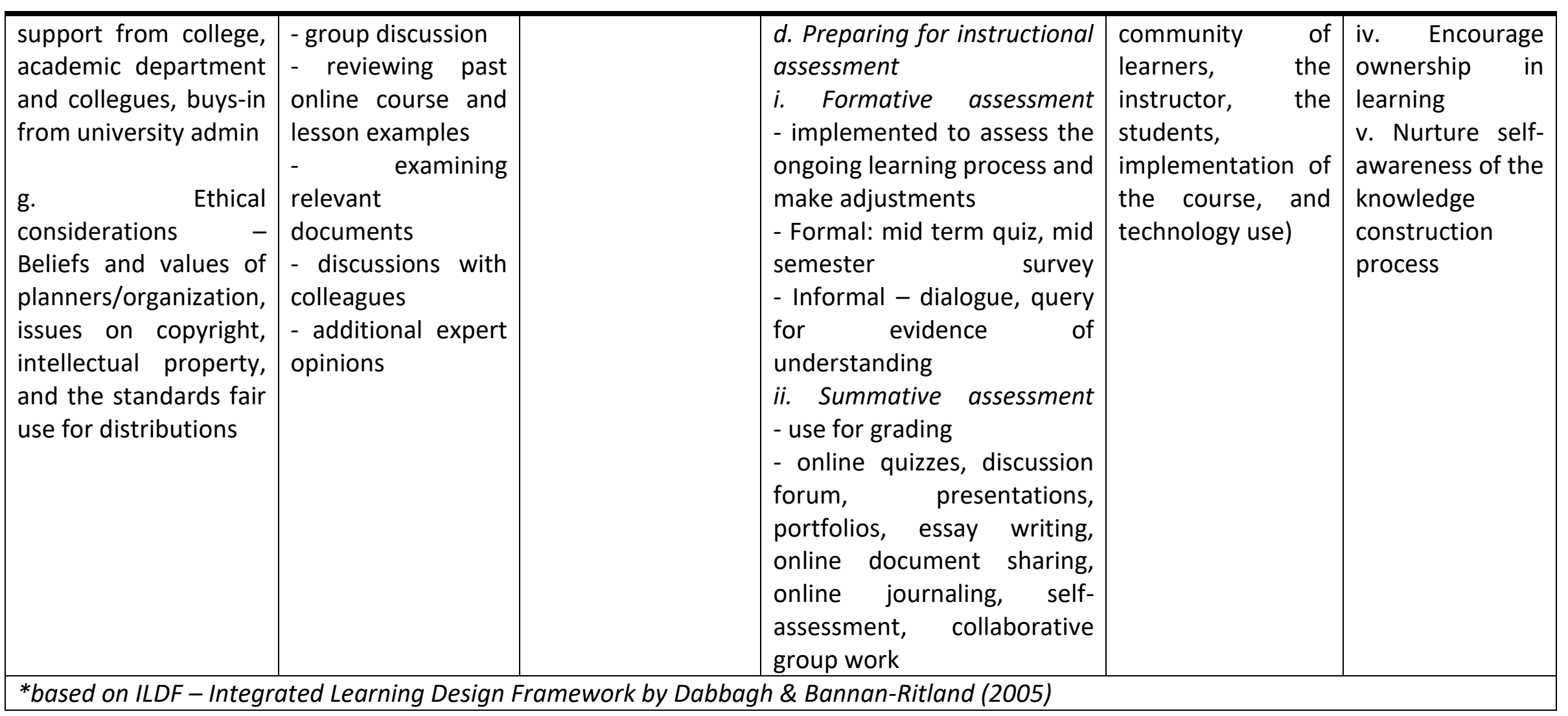


INTERNATIONAL JOURNAL OF ACADEMIC RESEARCH IN BUSINESS AND SOCIAL SCIENCES

Vol. 8, No. 12, Dec, 2018, E-ISSN: 2222-6990 @ 2018 HRMARS

\section{Corresponding Author}

Nur Aira Abdrahim,

Senior Lecturer \& Member of PUTRA Future Classroom

Department of Professional Development and Continuing Education, Faculty of Educational Studies, Universiti Putra Malaysia.

Email: nuraira@upm.edu.my

Address: Department of Professional Development and Continuing Education, Faculty of Educational Studies, Universiti Putra Malaysia, 43400 UPM Serdang, Malaysia. 
INTERNATIONAL JOURNAL OF ACADEMIC RESEARCH IN BUSINESS AND SOCIAL SCIENCES

Vol. 8, No. 12, Dec, 2018, E-ISSN: 2222-6990 @ 2018 HRMARS

\section{References}

Alonso, F., López, G., Manrique, D., \& Viñes, J. M. (2005). An instructional model for web-based elearning education with a blended learning process approach. British Journal of Educational Technology, 36(2), 217-235. doi: 10.1111/j.1467-8535.2005.00454.x

Barr, R. B., \& Tagg, J. (1995). From teaching to learning: A new paradigm for undergraduate education. Change, 27(6), 12-25.

Bonk, C. J., \& Dennen, V. P. (2007). Frameworks for design and instruction. In M. G. Moore (Ed.), Handbook of distance education (2nd ed. ed., pp. 233-246). Mahwah, NJ: Lawrence Erlbaum Associates.

Boone, E. J., Safrit, R. D., \& Jones, J. (2002). Developing programs in adult education: A conceptual programming model (2nd ed.). Long Grove, IL: Waveland Press.

Brown, J. S. (1990). Toward a new epistemology for learning. In C. Frasson, \& G. Gauthier (Eds.), Intelligent tutoring systems: At the crossroad of artificial intelligence and education (pp. 266282). Norwood, N.J.: Ablex Publishing Corporation.

Brown, J. S., \& Dugurd, P. (2000). The social life of information. Boston, MA: Harvard Business School Press.

Caffarella, R. S. (2002). Planning programs for adult learners: A practical guide for educators, trainers, and staff developers (2nd ed.). San Francisco, CA: Jossey-Bass.

Cervero, R. M., \& Wilson, A. L. (1994). Planning responsibly for adult education: A guide to negotiating power and interests. San Francisco: Jossey-Bass.

Cervero, R. M., \& Wilson, A. L. (1998). Working the planning table: The political practice of adult education. Studies in Continuing Education, 20(1), 5-21. doi: 10.1080/0158037980200101

Cervero, R. M., \& Wilson, A. L. (2006). Working the planning table: Negotiating democratically for adult, continuing and workplace education. San Francisco, CA: Jossey-Bass.

Chau, P. (2010). Online higher education commodity. Journal of Computing in Higher Education, 22(3), 177-191. doi: 10.1007/s12528-010-9039-y

Clark, R. E. (2000). Evaluating distance education: Strategies and cautions. The Quarterly Review of Distance Education, 1(1), 3-16.

Cohen, V. L. (2003). A model for assessing distance learning instruction. Journal of Computing in Higher Education, 14(2), 98-120. doi: 10.1007/BF02940940

Dabbagh, N., \& Bannan-Ritland, B. (2005). Online learning: Concepts, strategies, and application. Upper Saddle River, NJ: Pearson Education.

Driscoll, M. P. (2000). Psychology of learning for instruction (2nd ed.). Needham Heights, MA: Allyn \& Bacon.

Forester, J. (1989). Planning in the face of power. Berkeley, CA: University of California Press.

Gboku, M., \& Lekoko, R. N. (2007). Developing programmes for adult learners in Africa. Hamburg, Germany: UNESCO Institute for Lifelong Learning.

Gunawardena, C. N., Lowe, C., \& Carabajal, K. (2000, February). Evaluating online learning: Models and methods. Paper presented at the Society for Information Technology and Teacher Education (SITE) Conference, San Diego, CA. 
INTERNATIONAL JOURNAL OF ACADEMIC RESEARCH IN BUSINESS AND SOCIAL SCIENCES

Vol. 8, No. 12, Dec, 2018, E-ISSN: 2222-6990 @ 2018 HRMARS

Hanna, D. E. (2003). Organizational models in higher education, past and future. In M. G. Moore, \& W. G. Anderson (Eds.), Handbook of distance education (pp. 67-78). Mahwah, NJ: Lawrence Erlbaum Associates.

Harasim, L. (2000). Shift happens: Online education as a new paradigm in learning. The Internet and Higher Education, 3(1-2), 41-61. doi: 10.1016/S1096-7516(00)00032-4

Hofstede, G. (2004). Cultures and organizations: Software of the mind (2nd ed.). New York, NY: McGraw-Hill.

Ibarra, R. A. (2001). Beyond affirmative action: Reframing the context of higher education. Madison, WI: University of Wisconsin Press.

Kelderman, E. (2011, November 6). Online programs face new demands from accreditors. Chronicles of Higher Education. Retrieved from http://chronicle.com.prox.lib.ncsu.edu/article/OnlinePrograms-Face-New/129608/

Kim, J. S. (2005). The effects of a constructivist teaching approach on student academic achievement, self-concept, and learning strategies. Asia Pacific Education Review, 6(1), 7-19. doi: 10.1007/BF03024963

Kleiber, P. B. (1996). Leveling the playing field for planning university-based distance education. New Directions for Adult and Continuing Education, 69, 59-68.

Knowles, M. S. (1990). The adult learner: A neglected species (4th ed.). Houston, TX: Gulf Publication Company.

Kozma, R. (2000). The relationship between technology and design in educational technology research and development: A reply to richey. Educational Technology Research \& Development, 31(9), 28-33.

Morrison, G. R., Ross, S. M., Kalman, H. K., \& Kemp, J. E. (2011). Designing effective instruction (6th ed.). Hoboken, NJ: John Wiley \& Sons.

Naidu, S. (2007). Instructional designs for optimal learning. In M. G. Moore (Ed.), Handbook of distance education (2nd ed. ed., pp. 247-258). Mahwah, NJ: Lawrence Erlbaum Associates.

Poley, J. (2010). Globalization in online learning. In K. E. Rudestam, \& J. Schoenholtz-Read (Eds.), Handbook of online learning (2nd ed., pp. 173-196). Thousand Oaks, CA: Sage Publications.

Poltorak, A., \& Lerner, P. J. (2002). Essentials of intellectual property. New York: Wiley.

Prensky, M. (2001). Emerald article: Digital natives, digital immigrants Part 1. On the Horizon, 9(5), 16. doi: $10.1108 / 10748120110424816$

Roberts, J. M. (1996). The story of distance education: A practitioner's perspective. Journal of the American Society for Information Science, 47(11), 811-816.

Rovai, A. P. (2004). A constructivist approach to online college learning. The Internet and Higher Education, 7(2), 79-93. doi: 10.1016/j.iheduc.2003.10.002

Rovai, A. P., Ponton, M. K., \& Baker, J. D. (2008). Distance learning in higher education: $A$ programmatic approach to planning, design, instruction, evaluation, and accreditation. New York: Teachers College Press.

Rowley, D. J., Lujan, H. D., \& Dolence, M. G. (1997). Strategic change in colleges and universities. San Francisco, CA: Jossey-Bass.

Sandman, L. R., Kiely, R. C., \& Grenier, R. S. (2009). Program planning: The neglected dimension of service learning. Michigan Journal of Community Service Learning, 15(2). Retrieved from 
INTERNATIONAL JOURNAL OF ACADEMIC RESEARCH IN BUSINESS AND SOCIAL SCIENCES

Vol. 8, No. 12, Dec, 2018, E-ISSN: 2222-6990 @ 2018 HRMARS

http://www.freepatentsonline.com/article/Michigan-Journal-Community-Service-

Learning/213693943.html

Schon, D. (1983). The reflective practitioner. New York: Basic Books.

Simonson, M., Smaldino, S., Albright, M., \& Zvacek, S. (2009). Teaching and learning at a distance: Foundations of distance education (4th ed.). Boston, MA: Pearson Education.

Sork, T. J. (2000). Planning education programs. In A. L. Wilson, \& E. Hayes (Eds.), Handbook of adult and continuing education (pp. 171-190). San Francisco, CA: Jossey-Bass.

Sork, T. J. (2010). Planning and delivering programs. In C. E. Kasworm, A. D. Rose \& J. M. Ross-Gordon (Eds.), Handbook of adult and continuing education (2010 ed. ed., pp. 157-166). Thousand Oaks, CA: SAGE Publications.

Sork, T. J., \& Buskey, J. H. (1986). A descriptive and evaluative analysis of program planning literature, 1950-1983. Adult Education Quarterly, 36(2), 86-96. doi: 10.1177/0001848186036002003

Technology, Education and Copyright Harmonization (TEACH) Act, S 487 (2002). Retrieved from http://www.copyright.gov/docs/regstat031301.htmlTyler, R. (1949). Basic principles of curriculum and instruction. Chicago, IL: University of Chicago Press.

Warren, R. (2000). Program planning and development in adult education: Where we are at the beginning of the c1st century. Retrieved from https://web.utk.edu/ cdavis80/EP521/readings/Warren.pdf

Wiesenberg, F., \& Stacey, E. (2005). Reflections on teaching and learning online: Quality program design, delivery and support issues from a cross-global perspective. Distance Education, 26(3), 385-404. doi: 10.1080/01587910500291496

Wilson, A. L., \& Cervero, R. M. (2006). The song remains the same: The selective tradition of technical rationality in adult education program planning theory. International Journal of Lifelong Education, 16(2), 84-108. doi: 10.1080/0260137970160202 